pełnia Rektor Stefan Jurga oraz Metropolita Gnieźnieński ks. abp Henryk Muszyński. Ten ostatni dokonał poświęcenia budynku. Na zakończenie pierwszej części uroczystości chór zaprezentowal program artystyczny.

O godz. 10.30 rozpoczęla się uroczysta inauguracja roku akademickiego 2004/2005. Prorektor UAM prof. dr hab. Bogdan Walczak witając gości, pracowników CEG oraz studentów, podkreślił, jak ważne miejsce zajmuje UAM wśród uniwersytetów polskich. Uwydatnił rolę CEG w integracji kulturowej Europy oraz w kształtowaniu tożsamości narodowej i europejskiej polskiej młodzieży. Witajac studentów, docenił ich siłę, zapał oraz entuzjazm młodzieńczy. Przede wszystkim zaakcentowal grupę studentów pierwszego roku, kształcących się już w zjednoczonej Europie, którzy w pluralistyczną tożsamość Europy wpisuja swoją tożsamość ojczysta.

Dyrektor naukowy CEG prof. dr hab. Aleksander Mikołajczak zapoznał zebranych z osiagnięciami naukowymi Collegium, tematami konferencji naukowych oraz z podjętymi działaniami na rzecz badań kulturowych korzeni Europy.

Studenci nowego pierwszego roku edukacji europejskiej, europejskiej komunikacji społecznej oraz politologii złożyli ślubowanie oraz odebrali indeksy z rak Prorektora UAM prof. dr hab. Bogdana Walczaka. Uroczystości towarzyszył chór Schola Cantora z Kalisza.

Prof. dr hab. B. Walczak wręczył medale pamiątkowe CEG Metropolicie Gnieźnieńskiemu ks. abp Henrykowi Muszyńskiemu oraz Rektorowi prof. dr hab. Stefanowi Jurdze za pomoc w realizacji idei powstania Collegium. W podziękowaniach abp H. Muszyński podkreślił rolę UAM i CEG w kształtowaniu przyszłego oblicza nowej Europy i ojczyzny, którego podstawą jest bogactwo wewnętrzne każdego człowieka. Prof. dr hab. S. Jurga zwrócił uwagę na nowe wyzwania, jakie powinno podjąć Collegium: kulturowy dialog młodzieży, wyrażany także przez muzykę, teatr, ideę sportu. Przypomnial również, że CEG jest „dzieckiem” II Historycznego Zjazdu Gnieźnieńskiego.

Wykład inauguracyjny pt. „Na szlakach renesansowej Europy” wygłosiła prof. dr hab. Dorota Żołądź-Strzelczyk. Prelegentka przedstawiła nie tylko kierunki podróży renesansowej młodzieży polskiej, ale także zaprezentowala dodatnie, jak i ujemne skutki peregrynacji w opinii ówczesnych myślicieli.

Na zakończenie uroczystości zostały wręczone wyróżnienia dla sportowców CEG oraz odśpiewano Gaudeamus.

\title{
Powiązania rodzinne wśród twórców polskiej teorii i praktyki edukacyjnej, konferencja naukowa, Gniezno, 28 -30.11.2004 r.
}

W dniach 28 - 30 listopada 2004 r. w Collegium Europaeum Gnesnense odbyła się ogólnopolska sesja naukowa poświęcona znaczeniu rodziny w życiu i w działalności twórców koncepcji i ideologii wychowawczych. Przesłankę do zorganizowania konferencji stanowiła problematyka, nie będaca do tej pory przedmiotem glębszych rozważań na żadnym zjeździe historyków wychowania, a pozwalająca poznać uczestnikom, jak dokonywała się transmisja międzypokoleniowa w różnych środowiskach, epokach, w różnych regionach Polski.

Jej organizatorami były dwie placówki uniwersyteckie: Zakład Historii Wychowania Uniwersytetu Adama Mickiewicza w Poznaniu i Zakład Historii Edukacji Uniwersytetu Mikołaja Kopernika w Toruniu, a także dwie młode placówki naukowo-dydaktyczne: Collegium Europaeum Gnesnense i Łużycka Wyższa Szkoła Humanistyczna w Żarach. 
W trzydniowych obradach wzięło udział siedemnaście ośrodków akademickich, w tym jedenaście uniwersyteckich. Na podkreślenie zasługuje fakt aktywnego udziału młodych historyków wychowania.

Uroczystego otwarcia konferencji dokonał prof. dr hab. Wiesław Jamrożek - kierownik Zakładu Historii Wychowania UAM i rektor Łużyckiej Wyższej Szkoły Humanistycznej. Natomiast kanclerz tejże uczelni mgr inż. Izabela Kumor-Pilarczyk przedstawiła krótki rys historyczny uczelni w Żarach. W imieniu prorektora UAM w Poznaniu oraz dziekana Wydziału Studiów Edukacyjnych UAM, prof. dr. hab. Wiesława Ambrozika, uczestników powitała z kolei prodziekan WSE prof. dr hab. Dorota Żołąź-Strzelczyk. Zgromadzonych gości przywitali także studenci gnieźnieńskiego Collegium, którzy zaprezentowali przygotowany przez siebie film dotyczący uczelni i zapoznali uczestników z osiągnięciami, działalnością i dokonaniami szkoły.

W plenarnych częściach konferencji przedstawiono w sumie 10 referatów. Obradom przewodniczyli profesorowie: Eleonora Sapia-Drewniak (w pierwszym dniu), Wladysława Szulakiewicz (w drugim dniu) i Grzegorz Michalski (w trzecim dniu). W ramach dwóch sekcji zaprezentowano $z$ kolei 16 referatów. Przewodniczącymi pierwszej sekcji były profesor: Agnieszka Stopińska-Pajak i Danuta Koźmian, drugiej - prof. Tadeusz Jałmuźna.

Obrady zainaugurowała prof. dr hab. Wladysława Szulakiewicz (UAM) wystapieniem zatytułowanym „Biografistyka $i$ jej miejsce $w$ historii edukacji”. Swoje rozważania na powyższy temat podzieliła na cztery części. Pierwsza dotyczyla tradycji badań biograficznych, omówiona została biografia i jej rodzaje. Druga poruszała problemy źródeł w badaniach biograficznych. Szczególną uwagę referentka zwróciła na materiały pamiętnikarskie i ich wartość poznawczą, na dylematy odczytywania źródeł, znaczenie literatury pamiętnikarskiej w rekonstrukcji dziejów oświaty i pedagogiki. Kolejna część - trzecia poświęcona była problematyce miejsca biografistyki w historii edukacji. W. Szulakiewicz dokonała tu przeglądu piśmiennictwa, zwracając przede wszystkim uwagę na zasadnicze kierunki biografistyki galicyjskiej i tematykę biografistyki międzywojennej i powojennej. Czwarta, ostatnia część obejmowała zagadnienia wartości poznawczej biografistyki edukacyjnej i określała postawę badawcza historyka. Prof. dr hab. W. Szulakiewicz, podsumowując wyraziła swoją opinię, że badania biograficzne, tak jak inne badania nad kulturą polską należy kontynuować w celu przybliżenia Europie polskiej kultury i jej twórców.

W referacie „Rodzina i jej wptyw na poglady i dzialalność Heleny Witkowskiej (1870 - 1938) oraz Janusza Jędrzejewicza (1885-1951)" prof. dr hab. Danuta Koźmian (US) przybliżyła uczestnikom konferencji poglądy, działalność, koncepcje i losy życia wymienionych w tytule wystapienia przedstawicieli pedagogiki. O osiagnięciach i pracy $\mathrm{H}$. Witkowskiej, współtwórczyni koncepcji wychowania obywatelskiego, autorka jedynie wspomniała, skupiając się przede wszystkim na osobie J. Jędrzejewicza, pedagoga, którego myśl i działalność pedagogiczna kształtowała się pod znaczącym wpływem rodziny. Prof. dr hab. D. Koźmian zwróciła uwage na fakt, iż wszystko, co było ważne i miało zwiazek z biografią J. Jędrzejewicza zaczęło się w rodzinie. Źródła jego działalności wojskowej i politycznej tkwia według niej w patriotycznym i religijnym wychowaniu domowym.

Punktem wyjścia dla referatu pt. ",Wkład rodziny Moszczeńskich w rozwój polskiej edukacji”" prof. dr hab. Agnieszka Stopińska-Pająk (UŚ) uczyniła postać Izabeli Moszczeńskiej, osoby zaangażowanej na polu pedagogiki, andragogiki, działaczki społecznej i ruchu kobiecego, bardzo aktywnej w działalności politycznej i edukacyjnej. I. Moszczeńska pochodziła ze środowiska rodzinnego o silnych tradycjach patriotycznych, zaangażowanego na polu oświaty. Wszyscy członkowie rodziny uczestniczyli zatem w kreowaniu polskiej edukacji. Autorka wskazała na to, że wspólna działalność Moszczeńskich, ich misja oświatowa były ściśle związane z walką o polską szkołę i kulturę. Zwróciła uwagę na fakt, że niezbędne jest zatem ocalenie od zapomnienia ich dorobku i dokonań, że ich osiągnięcia są godne badań i pogłębionych analiz.

Interesujący, jednak mało znany wizerunek polskiego pedagoga, nauczyciela, wykładowcy S. Dobrowolskiego zaprezentował na konferencji prof. dr hab. Tadeusz Jałmużna (UŁ) w referacie pt. „Dom rodzinny $i$ jego oddziatywanie na zainteresowania $i$ dziatalność pedagogiczna Stanistawa Mariana Dobrowolskiego". Profesor omówił historię życia, losy, edukację i działalność pedagogiczną 
bohatera swojego wystapienia, skoncentrowaną wokół dwóch problemów: oświaty rolniczej i pedeutologii. Zwrócił uwagę na fakt, że aktywność S. Dobrowolskiego zwiazana była z jego domem rodzinnym i z własną rodzina, która wspierała go i uczestniczyła w jego działaniach pedagogiczno-oświatowych. Prof. dr hab. T. Jałmużna kończąc swoje wystąpienie podkreślił, że wśród podstawowych kręgów środowiskowych rodzina spełnia rolę najważniejsza, jest autorytetem wychowawczym, który rodzi się w czasie bezpośrednich kontaktów między wychowującym a wychowankiem.

Drugi dzień obrad plenarnych rozpoczał się referatem prof. dr hab. Eleonory Sapi-Drewniak (UO) pt. „Rola dziadków w ksztaltowaniu postawy życiowej Stefanii Mazurek - organizatorki edukacji dzieci i dorostych na Ślasku". Autorka scharakteryzowała rolę i znaczenie Franciszki Morgałowej w życiu jej wnuczki - Stefanii. Mówiła o tym, jak kontakty z babcia przyczyniły się do wyboru drogi osobistej i zawodowej Stefanii Mazurek, która dzięki normom i wartościom politycznym wyniesionym z domu rodzinnego stala się osoba o silnie ukształtowanej przynależności narodowej, angażująca się w sprawy kraju, dla której, tak jak i dla babci, celem życia była Polska. Referentka zwróciła uwagę na to, że starsze pokolenia dażą do tego, aby przekazać młodym dotychczasową historię, która wiążą ze Środowiskiem lokalnym. Działania te służa, jej zdaniem, wzmocnieniu więzi między nimi i rozbudzeniu tożsamości narodowej, a także wpływaja na dalsze losy najmłodszych.

Kwestii „Dzialalności rodziny Arctów na rzecz edukacji” poświęcone było wystapienie dr Iwonny Michalskiej i prof. dr hab. Grzegorza Michalskiego (UE). W prezentowanym referacie wyodrębniono trzy części. Pierwsza dotyczyła koligacji rodzinnych, określała funkcje i role, jakie pełnili w firmie Arctów poszczególni członkowie rodziny, a także sposób, w jaki przygotowani byli do zawodu księgarskiego. Druga została poświęcona historii i dziejom firmy Arctów, założonej przez Stanisława Arcta w Lublinie, w roku 1838. Trzeci problem koncentrował się wokół dbałości Arctów o edukację, czyli ich działalności wydawniczej nastawionej na rozpowszechnianie dzieł pedagogicznych, ksiażek szkolnych i literatury dla dzieci i młodzieży. Referenci zwrócili uwagę na to, że ta rodzina księgarzy i wydawców potrafiła zaspokoić wymagania swoich czytelników i w znacznym stopniu przyczyniła się do edukowania społeczeństwa polskiego.

Kolejny referat, wygłoszony przez dr Edytę Glowacka-Sobiech pt. „Kamykowe matzieństwo. Rzecz o Janinie i Aleksandrze Kamińskich", był próba pokazania, jak ważne jest będąc osoba publiczną mieć zwyczajną rodzinę i oparcie w życiowej partnerce. Referentka wskazała na rolę, jaka odegrała w życiu Kamińskiego jego żona, która dzieliła z nim wspólne pasje, zainteresowania, wspierała go moralnie, opiekowała się nim, była jego najlepszym przyjacielem, a po śmierci męża, utrwalała jego nazwisko i pielęgnowała spuściznę po nim.

Należy również wspomnieć o tym, że niewatpliwa atrakcja, przygotowana przez organizatorów w drugim dniu konferencji było zwiedzanie Gniezna, wycieczka "śladami pierwszych Piastów". W Muzeum Poczatków Państwa Polskiego goście mieli okazję obejrzeć prezentację typu światło i dźwięk, która ukazywała najstarsze dzieje i kulturę państwa Piastów. Imponująca była także kolekcja obrazów historycznych polskich malarzy z XIX w. i zbiory archeologiczne. Kolejny etap wycieczki stanowiło Muzeum Archidiecezji Gnieźnieńskiej, z ciekawą ekspozycja sztuki sakralnej. Zwiedzanie miasta zakończyło się w Katedrze pw. Wniebowzięcia NMP i św. Wojciecha.

Obrady popołudniowe odbyły się w dwóch sekcjach. Na posiedzeniu sekcji I, której przewodniczyły prof. dr hab. D. Koźmian i prof. dr hab. A. Stopińska-Pająk zaprezentowano następujace referaty:

- „Jadwiga i Jagielto a odnowienie Uniwersytetu Krakowskiego" - dr K. Ratajczak

- „Dzialalność oświatowa przedstawicieli rodu Potockich" - dr hab. Adam Winiarz

- „Ekologiczne przestanki w twórczości naukowej Jana i Jędrzeja Śniadeckich" - dr E. Wolter

- „Idealy wychowawcze w rodzinie Ledóchowskich" - ks. dr E. Wieczorek

- „W kregu Hoffmanowej” - dr J. Dabrowska

- "Wspótpraca Mieczystawa i Adama Baranowskich z czasopismem Szkoła" - mgr D. Lęcka

- „Rzeczpospolita Lutycka - marzenie Olgi i Andrzeja Małkowskich" - mgr S. Hubicka

- „Bogactwo zycia i dzialalność Marii Weryho-Radziwitlowiczowej” - mgr K. Wira-Świątkowska 
W sekcji II, której przewodniczył prof. dr hab. T. Jałmużna, przedstawiono z kolei referaty o tematyce:

- „Wklad Teodory i Wacława Męczkowskich w rozwój polskiej pedagogiki” - dr M. Posłuszna

- "Dzialalność pedagogiczna i oświatowa Czackich" - dr D. Apanel

- "Spoteczno-edukacyjna działalność sióstr Sokolnickich" - dr J. Gulczyńska

- „Spoteczno-edukacyjna aktywność rodziny Krzywickich" - mgr K. Łozowska

- „Jan Hulewicz - lwowsko-krakowskie korzenie" - dr K. Buczek

- "Spoteczno-edukacyjna dziatalność Ludwika i Stefanii Posadzy" - mgr J. Kowalska Wałega

- "Srodowisko rodzinne a dzialalność pedagogiczna Wandy i Stefana Szumanów" - mgr A.

- „Ewy i Feliksa Przylubskich oraz Janiny i Antoniego Maćkowiaków dziatalność na rzecz edukacji wczesnoszkolnej" - mgr S. Waszczykowska

Koncepcję Wiejskiego Uniwersytetu Ludowego, będącego instytucją oświaty dorosłych , omówił w ostatnim dniu obrad prof. dr hab. Wiesław Jamrożek (UAM i ŁWSH) w referacie zatytułowanym "Ignacy i Zofia Solarzowie twórcy Uniwersytetu Ludowego $w$ Szycach". Prof. W. Jamrożek wypowiadał się na temat działalności Ignacego i Zofii Solarzów, którzy stworzyli Uniwersytet mający być zakładem wychowawczym o charakterze ogólnokształcącym; chodziło im przede wszystkim o kształtowanie światopoglądu, świadomości społecznej, o przygotowanie do współuczestnictwa w społeczno-kulturowym życiu wsi i narodu.

Bohaterem następnego z kolei wystapienia dr Nella Stolińska-Pobralska i mgr Jerzy Pobralski (UŁ) uczynili pedagoga opiekuńczego, twórcę systemu wychowawczego ognisk - Kazimierza Lisieckiego. W referacie pt. „Biograficzne uwarunkowania systemu wychowania Kazimierza Lisieckiego" zaprezentowali koncepcję ognisk wychowawczych, przeznaczonych dla dzieci i młodzieży dotkniętych sieroctwem społecznym, sprawiających problemy spoleczne, pochodzacych $\mathrm{z}$ rodzin o trudnych warunkach bytowych. Celem $\mathrm{K}$. Lisieckiego bylo nadanie tym ośrodkom rodzinnego charakteru. Autorzy referatu przyznali, że temat konferencji „Powiazania rodzinne..." został potraktowany przez nich dosyć przewrotnie, bowiem K. Lisiecki był sierota rodzinę stracił $\mathrm{w}$ wieku 13 lat. W zwiazku z tym wystappieniem starano się udowodnić tezę, że rodzina duchowa, z która nie wiąża czlowieka więzy krwi może być tak samo ważna, jak rodzina
naturalna.

Referat zatytułowany "Studenci z rodzin nauczycielskich w Akademii Pedagogicznej w Krakowie w latach 1999 - 2004" przedstawiła dwójka krakowskich historyków dr Jan Ryś i dr Ryszard Ślęczka. Celem ich badań, które objęły studentów uczelni pedagogicznej, było poszukiwanie odpowiedzi na pytanie: ,Jak w rodzinach nauczycielskich wygląa proces dziedziczenia zawodu?". Starali się sprawdzić, czy młodzież pochodząca $z$ rodzin nauczycielskich jest bardziej dojrzała do wykonywania tego zawodu, czy jej decyzje sa przemyślane, jakie są ich motywacje, czy dobrze znają ten zawód i czy rokuja, iż będa w przyszłości dobrymi pedagogami. Podsumowując swoje badania autorzy wyrazili niepokój, że wśród młodych ludzi decydujących się na pełnienie roli wychowawców jest tak niewiele miłości i powołania, a przecież od tego, jakich mamy nauczycieli zależy, jaką będziemy mieć szkołę.

Ostatecznej oceny przebiegu i efektów trzydniowego spotkania podjęła się prof. dr hab. W. Szulakiewicz. W swoim wystapieniu zaakcentowała znaczenie rodziny dla szeroko rozumianej praktyki edukacyjnej i działalności kulturalnej. Wyniki obrad w sekcjach przedstawili z kolei ich przewodniczacy, czyli: prof. dr hab. T. Jałmużna (sekcja II) i ks. dr E. Wieczorek, występujący w imieniu przewodniczących sekcji I. Uroczystego i oficjalnego zamknięcia obrad na temat: „Powiązania rodzinne wśród twórców teorii i praktyki edukacyjnej” dokonał prof. dr hab. W. Jamrożek, współorganizator konferencji. 